\title{
Effect of Process Parameters on the Physical Properties of Watermelon Seed Oil under Uniaxial Compression
}

\author{
Nwosu Caesar ${ }^{1 *}$, Ozumba Isaac $\mathrm{C}^{1}$ and Kabir Abdullahi $\mathbf{O}^{2}$ \\ ${ }^{1}$ Agro-Industrial Development and Extension Department, National Centre for Agricultural Mechanization, Nigeria \\ ${ }^{2}$ Agricultural and Bio systems Engineering Department, University of Ilorin, Nigeria
}

Submission: May 01, 2017; Published: November 17, 2017

*Corresponding author: Nwosu Caesar, Agro-Industrial Development and Extension Department, National Centre for Agricultural Mechanization, Nigeria, Email: caesarjn123@gmail.com

\begin{abstract}
The effect of process parameters such as temperature and pressure on the physical properties of watermelon seed oil under uniaxial compression was studied. A laboratory mechanical oil expression piston-cylinder rig was used to express oil from watermelon seeds at different temperatures $\left(100^{\circ} \mathrm{C}, 110^{\circ} \mathrm{C}, 120^{\circ} \mathrm{C}\right.$ and $\left.130^{\circ} \mathrm{C}\right)$ and different pressures $(5000 \mathrm{Kg}, 5500 \mathrm{Kg}, 6000 \mathrm{Kg}$ and $6500 \mathrm{Kg})$. The expressed oil was analyzed for Viscosity, Specific gravity, Refractive Index and Boiling Point using standard methods. The results obtained were subjected to statistical analysis using Analysis of variance (ANOVA).

The results revealed that viscosity of the expressed oil consistently decreased with increase in heating temperature for all the pressure regimes under study and increased with increasing applied pressure for all temperature regimes under study. The results also showed that process conditions did not affect the specific gravity of the expressed oil in a particular pattern. The study further revealed that an increase in heating temperature and applied pressure results in a corresponding significant increase in the refractive index of the expressed oil. It was also revealed in this study that while increasing temperature reduces Boiling point, increasing pressure increases the Boiling point of oil mechanically expressed from watermelon seed. It is therefore concluded that for optimal physical properties of oil expressed from watermelon seeds, temperature and pressure must be regulated.
\end{abstract}

\section{Introduction}

Vegetable oils are essential in meeting global nutritional demands and are utilized for many food and Industrial purposes [1]. In Nigeria, vegetable oils are gaining popularity in food, medical, cosmetic and soap making industries for the production of edible oils, drugs, pomade and toilet soaps respectively. Although there is a wide range of vegetable oil sources, the Nigerian vegetable oil production is dominated by palm olein, groundnut and soya bean.

Watermelon seeds are one of the known oil bearing seeds with high nutritional importance. Its oil is used in cooking and can be incorporated into the production of cosmetics [2]. Watermelon seeds are rich sources of protein, vitamins $\mathrm{B}$, minerals (such as magnesium, potassium, phosphorous, sodium, iron, zinc, manganese and copper) and fat among others as well as phytochemicals. According to [2], its seed averagely consist of $31.9 \%$ protein, $4.4 \%$ carbohydrates, $57.1 \%$ fat, $8.2 \%$ fiber, $6.2 \%$ ash, $130 \mathrm{mg}$ calcium, $456 \mathrm{mg}$ phosphorus, and $7.5 \mathrm{mg}$ iron. It also contains the necessary amino acids such as Leucine, Isoleucine, Tryptophan and Valine [3].

According to [4], watermelon seed oil contains high amounts of unsaturated fatty acids with linoleic and oleic acids as the major acids. Conventionally, the seeds are removed from the pod and then allowed to dry outside in the sun to significantly reduce its moisture content. Once dried, the seeds are then pressed to extract the useful oil. In Nigeria, the traditional method of vegetable oil extraction is still in use; products from this method have limited application due to poor quality of oil obtained from this process. According to [5], the Nigerian vegetable oil production industry has been characterized by low production capacity, low extraction rate of (12-18) \% and low quality of produced oil (FFA greater than 10\%).

This low extraction rate and poor quality oil can be attributed to the process and the equipment used for the expression. In view of the increasing awareness of the use of 
watermelon seed oil; there is need to know the appropriate sets of parameters necessary for the optimum quality extraction of the oil. This study is therefore focused at investigating the quality of oil recovered during mechanical expression of oil from unshelled watermelon seed at different temperatures and pressures.

\section{Materials and Methods}

All experimental investigations were carried out in the Food Processing laboratory of the National Centre for Agricultural Mechanization (NCAM), Ilorin, Nigeria. The average room temperature of the laboratory throughout the duration of the experimental works was averagely $30^{\circ} \mathrm{C}$.

\section{Material preparation}

Watermelon seeds used in this experiment was obtained from an open market in Ilorin, Kwara State, Nigeria. The unshelled seeds were sorted and cleaned to remove stones and other foreign materials. The moisture content of the seeds was determined using method prescribed by [6] and was found to be $4.25 \% \mathrm{wb}$. The seeds were then packed into air tight containers and placed in the laboratory.

\section{Experimental machines and instrumentation}

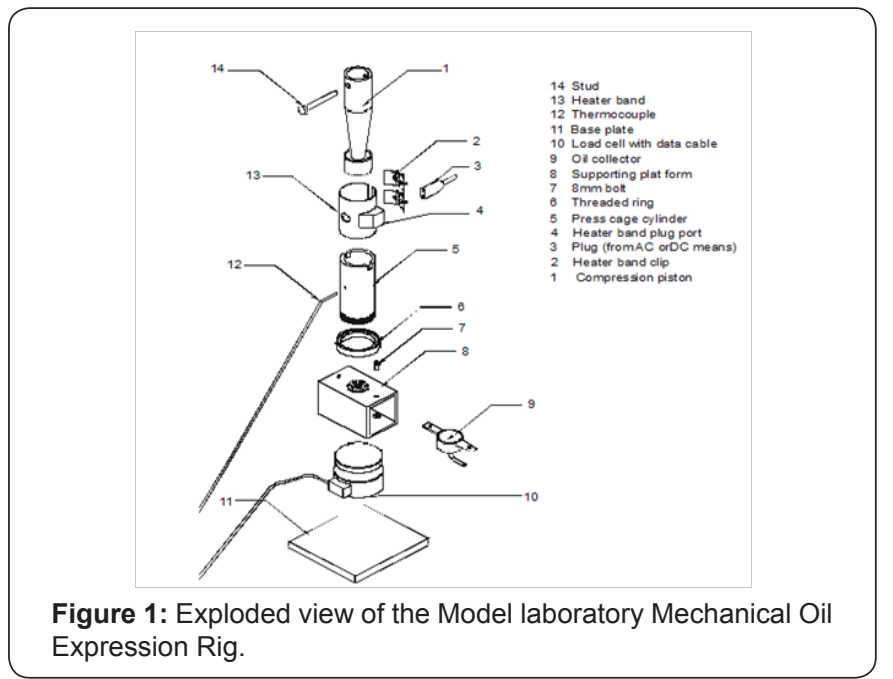

In this study, a technique for heating oil seed sample before and during expression was adopted. A laboratory mechanical oil expression piston-cylinder rig, developed and used by [7] was used for this experiment. The laboratory mechanical oil expeller is made up of three major components: the compression piston, the press cage cylinder and the supporting platform. A $600 \mathrm{~W}$ electric band heater was installed round the press cage cylinder to serve as a heating device for the expression process, while a thermocouple probe was used to monitor the temperature of the sample during preheating and expression process. The rig was adequately instrumented with a temperature controller to control the expression temperature, while the pressure for oil expression was obtained from the hydraulic press via the instrumentation system (force measuring device) (Figure 1).

\section{Experimental Design}

In order to study the effects of process conditions such as heating temperature and applied pressure on the physical properties of oil mechanically expressed from watermelon seeds; a suitable experimental design that incorporated four levels of heating temperature (i.e., $100{ }^{\circ} \mathrm{C}, 110{ }^{\circ} \mathrm{C}, 120$ ${ }^{\circ} \mathrm{C}$ and $130{ }^{\circ} \mathrm{C}$ ), four levels of applied pressure (i.e., $5000 \mathrm{~kg}$, $5500 \mathrm{~kg}, 6000 \mathrm{~kg}$ and $6500 \mathrm{~kg}$ ) was designed. A $4 \times 4$ factorial experimental design in a Complete Randomized Block Design (CRBD) was used. Each test was performed in three replicates at each level of the factors. The ranges of values of these factors were obtained from literature search and preliminary test on watermelon oil expression.

Table 1: Design layout of $4 x 4$ Factorial Experiment under Complete Randomize Block Design (CRBD).

\begin{tabular}{|c|c|}
\hline T1P1 & T3P1 \\
\hline T1P2 & T3P2 \\
\hline T1P3 & T3P3 \\
\hline T1P4 & T3P4 \\
\hline T2P1 & T4P1 \\
\hline T2P2 & T4P2 \\
\hline T2P3 & T4P3 \\
\hline T2P4 & T4P4 \\
\hline
\end{tabular}

Key: T=Temperature; $\mathrm{T} 1=100{ }^{\circ} \mathrm{C} ; \mathrm{T} 2=110{ }^{\circ} \mathrm{C} ; \mathrm{T} 3=120{ }^{\circ} \mathrm{C} ; \mathrm{T} 4=130$ ${ }^{\circ} \mathrm{C} ; \mathrm{P}=$ Pressure; $\mathrm{P} 1=5000 \mathrm{~kg} ; \mathrm{P} 2=5500 \mathrm{~kg} ; \mathrm{P} 3=6000 \mathrm{~kg} ; \mathrm{P} 4=6500 \mathrm{~kg}$

Other important factors such as moisture content, particle size, heating time and pressing time were also obtained through preliminary investigations and were kept constant throughout the experiments in order to reduce the data to a reasonable size. The layout of the $4 \times 4$ factorial design experiments is as shown in Table 1.

\section{Sequence of Mechanical Oil Expression}

Before coupling the mechanical oil expression rig, a stainless steel wire mesh was placed at the bottom of the cylinder guide in order to cover the drainage area and at the same time serve as a filter during the oil expression process. After the coupling, a sample of $200 \mathrm{~g}$ weight of unshelled watermelon seeds was poured into the press cage cylinder. The sample was then heated for 30 minutes at $100{ }^{\circ} \mathrm{C}$. Using the actuating lever of the hydraulic press, the compression piston was moved down to compress the sample inside the press cage cylinder to a pressure of $5000 \mathrm{~kg}$ for 10 minutes. The oil expressed drains into the oil collector and was collected through the outlet pipe.

On the expiration of the pressing time, the compression piston was lifted above the press cage using the actuating lever of the hydraulic press and the resulting cake was discarded. The same procedure was followed to carry out the experiment for three other heating temperature levels of $110{ }^{\circ} \mathrm{C}, 120^{\circ} \mathrm{C}$ and $130{ }^{\circ} \mathrm{C}$ and three other applied pressure levels of $5500 \mathrm{~kg}$, $6000 \mathrm{~kg}$, and $6500 \mathrm{~kg}$. Each experiment was carried out in three replicates. 


\section{Determination of physical properties of expressed} oil

The physical characteristics (quality) of the expressed oil at the various levels of heating temperatures and applied pressure were determined. The analyses were carried out using method recommended by [6] at the Chemistry Laboratory of the University of Ilorin, Nigeria. The physical properties of the expressed oil determined are viscosity, specific gravity, refractive index and Boiling point.

\section{Results and Discussion}

The summary of the results of the physical properties of watermelon oil mechanically expressed at different temperatures and pressures are presented in Table 2.

Table 2: Summary of Physical properties of watermelon oil.

\begin{tabular}{|c|c|c|c|c|c|}
\hline \multirow{2}{*}{\multicolumn{2}{|c|}{ Heating Temperature $\left({ }^{\circ} \mathrm{C}\right)$}} & \multicolumn{4}{|c|}{ Applied Pressure (Kg) } \\
\hline & & 5000 & 5500 & 6000 & 6500 \\
\hline \multirow{4}{*}{ Viscosity } & 100 & 10.5728 & 10.9903 & 11.2336 & 11.895 \\
\hline & 110 & 10.2424 & 10.5728 & 10.9903 & 11.8494 \\
\hline & 120 & 9.912 & 10.2425 & 10.5728 & 11.2336 \\
\hline & 130 & 9.5816 & 9.912 & 10.2426 & 10.9903 \\
\hline \multirow{4}{*}{ Specific Gravity } & 100 & 0.907 & 0.91 & 0.91 & 0.908 \\
\hline & 110 & 0.908 & 0.91 & 0.908 & 0.906 \\
\hline & 120 & 0.906 & 0.912 & 0.905 & 0.904 \\
\hline & 130 & 0.905 & 0.91 & 0.903 & 0.904 \\
\hline \multirow{4}{*}{ Refractive Index } & 100 & 1.46 & 1.462 & 1.464 & 1.467 \\
\hline & 110 & 1.462 & 1.463 & 1.465 & 1.467 \\
\hline & 120 & 1.462 & 1.464 & 1.466 & 1.468 \\
\hline & 130 & 1.463 & 1.465 & 1.467 & 1.468 \\
\hline \multirow{5}{*}{ Boiling Point $\left({ }^{\circ} \mathrm{C}\right)$} & & & 1 & & \\
\hline & 100 & 168.6 & 68.9 & 169.1 & 169.5 \\
\hline & 110 & 165.9 & 166.3 & 166.5 & 167.1 \\
\hline & 120 & 159.8 & 159.9 & 160.1 & 161.5 \\
\hline & 130 & 156.8 & 158.7 & 159.1 & 160.2 \\
\hline
\end{tabular}

Effect of process parameters on the viscosity of watermelon seed oil

Oils with lower values of viscosity and density are highly appreciable to consumers. In order to design an advanced technological process these properties are very important parameters. The effect of heating temperature and applied pressure on the viscosity of oil mechanically expressed from watermelon is shown in Table 2. From the table, it could be observed that the viscosity decreased from $11.8950 \mathrm{~cm} / \mathrm{sto}$ $9.5816 \mathrm{~cm} / \mathrm{s}$ as temperature increased from $100{ }^{\circ} \mathrm{C}$ to $130{ }^{\circ} \mathrm{C}$ while pressure decreased from $6600 \mathrm{Kg}$ to $5000 \mathrm{Kg}$. it could also be observed that the viscosity of the expressed oil consistently decreased with increase in temperature for all the pressure regimes under study and increased with increasing applied pressure for all temperature regimes under study.

This could be attributed to the thermal denaturing of intermolecular bonds between the oil molecules, allowing the molecules to speed up and spread out, thus resulting in low viscosity values. Oils are mixtures of triglycerides (TGs) and their viscosity depends on the nature of the TGs present in the oil. The viscosity changes could also be due to the different arrangement of the fatty acids on the glycerol backbone of the triglyceride molecule. With this in view, viscosity could be said to be related to the chemical properties of the oils such as chain length and saturation/unsaturation. This is similar to the findings of [8] and [9].

The researchers reported that increase in temperature consistently reduced the viscosity of oil mechanically expelled from palm kernel. Lubricating properties of oil generally are assessed based on their viscosity. Vegetable oils that are more viscose have better lubricating qualities. This study then shows that oil expressed from unshelled watermelon seeds, pre-heated at temperatures between $100{ }^{\circ} \mathrm{C}$ and $110{ }^{\circ} \mathrm{C}$ and expelled with $6500 \mathrm{Kg}$ of pressure will have high lubricating properties. 
Nutrition \& Food Science International Journal

Table 3: ANOVA output for the effect of process parameters on the viscosity of expressed oil

\begin{tabular}{|c|c|c|c|c|c|c|}
\hline Source of Variation & SS & df & MS & F & P-value & F crit \\
\hline Pressure & 2.326496 & 3 & 0.775499 & 152.2908 & $4.97 \mathrm{E}-08$ & 3.862548 \\
\hline Temperature & 4.366542 & 3 & 1.455514 & 285.8307 & $3.06 \mathrm{E}-09$ & 3.862548 \\
\hline Error & 0.04583 & 9 & 0.005092 & & & \\
\hline Total & 6.738868 & 15 & & & & \\
\hline
\end{tabular}

Table 3 shows the ANOVA output of the effect of heating temperature and applied pressure on the viscosity of the expressed oil. From the table, it could be observed that both heating temperature and applied pressure had significant effect on the viscosity of the expressed oil.

The significant decrease in viscosity value observed when the heating temperature was increased from $100{ }^{\circ} \mathrm{C}$ to 130 ${ }^{\circ} \mathrm{C}$ could be attributed to denaturing of the oil as a result of excessive burning due to high heating temperature. At heating temperature of $130{ }^{\circ} \mathrm{C}$, excessive burning of oil and cake occurred in addition to thermo-oxidation of oil. All these reduced the viscosity of the watermelon oil expressed at this temperature, thus making it unfit to be used as a lubricant.

\section{Effect of process parameters on the specific gravity of watermelon seed oil}

The effect of heating temperature and applied pressure on specific gravity of oil mechanically expressed from watermelon is as shown in Table 2 while the ANOVA output is presented in Table 4. From Table 2, it could be seen that the process parameters (Temperature and Pressure) did not affect the specific gravity of the expressed oil in a particular pattern. The values of specific gravity obtained were within the range of recommended specific gravity for edible oil [10].

From Table 4 it could be observed that while heating temperature had little significant effect, applied pressure had no significant effect on the specific gravity of the expressed oil. The significant effect of temperature on specific gravity of the expressed oil may have resulted from the increase in heating temperature. It appears that as the heating temperature increases; the molecular bonds were weakened; allowing the individual molecules free movement over each other, thus increasing the volume of the oil and reducing its specific gravity. This is similar to the findings of $[8,9,11]$. However, [8] in their work on palm kernel oil observed that the specific gravity of the expressed oil decreased consistently from 0.908 to 0.894 as the heating temperature was increased from $70{ }^{\circ} \mathrm{C}$ to 130 ${ }^{\circ} \mathrm{C}$. Thus, while their values of specific gravity were similar, the effect of temperature on the specific gravity of their expressed oil followed a particular pattern at $4.5 \%$ moisture content.

Table 4: ANOVA output for the effect of process parameters on specific gravity of expressed oil

\begin{tabular}{|c|c|c|c|c|c|c|}
\hline Source of Variation & SS & df & MS & F & P-value & F crit \\
\hline Pressure & $8.22 \mathrm{E}-06$ & 2 & $4.11 \mathrm{E}-06$ & 1.681818 & 0.295077 & 6.944272 \\
\hline Temperature & $6.49 \mathrm{E}-05$ & 2 & $3.24 \mathrm{E}-05$ & 13.27273 & 0.017149 & 6.944272 \\
\hline Error & $9.78 \mathrm{E}-06$ & 4 & $2.44 \mathrm{E}-06$ & & & \\
\hline Total & $8.29 \mathrm{E}-05$ & 8 & & & & \\
\hline
\end{tabular}

Proceeding on the assumption that this experiment is well behaved, it could then be said that the specific gravity of watermelon oil behaves slightly different from palm kernel oil under similar temperature conditions. The weight of oil in bulk shipments is assessed based on the specific gravity of the oil.

\section{Effect of process parameters on the refractive index of watermelon seed oil}

The effect of heating temperature and applied pressure on the refractive index of oil mechanically expressed from watermelon is shown in Table 2. From the table, it could be observed that the refractive index of watermelon oil increased from 1.460 to 1.468 when temperature and pressure increased from $100{ }^{\circ} \mathrm{C}$ to $130{ }^{\circ} \mathrm{C}$ and $5000 \mathrm{~kg}$ to $6500 \mathrm{~kg}$ respectively. This implies that an increase in heating temperature and applied pressure of the watermelon seeds leads to a corresponding increase in the refractive index of the oil extracted. This gradual increase in refractive index as the heating temperature increased could be attributed to excessive burning of the oil. It appears that as the temperature increased to $130{ }^{\circ} \mathrm{C}$, the oil became slightly burnt and thus increasing the refractive index. The values of refractive index obtained in this study are within the recommended range of 1.448 to 1.477 for edible vegetable oil [10], and compares favourably with the values obtained by other investigators for related vegetable oils and fats. For instance, [12] reported 1.465 to 1.475 for Shea butter, [13] reported 1.465 for rubber oil and [14] reported 1.467 to 1.472 for groundnut oil. The ANOVA output for the effect of heating temperature and applied pressure on the refractive index of mechanically expressed watermelon oil is presented in Table 5.

From Table 5, it could be seen that both temperature and pressure has significant effect on the refractive index of the expressed oil. Refractive index is the ratio of the velocity of light in a vacuum to that in a specified medium (watermelon oil). It is a physical property of oil used for rapid sorting of fats and oil to avoid adulteration, due to its ease of determination. 
Nutrition \& Food Science International Journal

Table 5: ANOVA output for the effect of process parameters on refractive index of expressed oil.

\begin{tabular}{|c|c|c|c|c|c|c|}
\hline Source of Variation & SS & df & MS & F & P-value & F crit \\
\hline Pressure & $4.22 \mathrm{E}-06$ & 2 & $2.11 \mathrm{E}-06$ & 19 & 0.00907 & 6.944272 \\
\hline Temperature & $2.02 \mathrm{E}-05$ & 2 & $1.01 \mathrm{E}-05$ & 91 & 0.000462 & 6.944272 \\
\hline Error & $4.44 \mathrm{E}-07$ & 4 & $1.11 \mathrm{E}-07$ & & & \\
\hline Total & $2.49 \mathrm{E}-05$ & 8 & & & & \\
\hline
\end{tabular}

Effect of process parameters on the boiling point of mechanically expressed from watermelon seed.

\section{watermelon seed oil}

The effect of heating temperature and applied pressure on the Boiling point of oil mechanically expressed from watermelon is shown in Table 2. From the Table2, it could be observed that the boiling point decreased consistently with increase in temperature from 168.60 to 156.80 when temperature was increased from $100{ }^{\circ} \mathrm{C}$ to $130{ }^{\circ} \mathrm{C}$ at a pressure of $5000 \mathrm{Kg}$.

This is true for all the pressure regimes under consideration. It could also be seen from the table that the boiling point increased consistently as applied pressure was increased from $5000 \mathrm{Kg}$ to $6500 \mathrm{Kg}$. It could therefore be deduced from this study that while increasing temperature reduces boiling point, increasing pressure increases the boiling point of oil
This consistent decrease in boiling point as temperature increased could be attributed to the thermal breakdown of molecular bonds within the oil cells at higher temperature. It appears that at higher temperatures, the molecular bonds are broken down or denatured in an irreversible reaction, thus, altering its boiling point permanently. The ANOVA output for the effect of heating temperature and applied pressure on the boiling point of mechanically expressed watermelon oil is presented in Table 6.

From the Table 6, it could be observed that the effect of temperature and pressure on boiling point of the expressed oil was very significant. The knowledge of boiling point is useful in the processing of watermelon seed oil into secondary products.

Table 6: ANOVA output for the effect of process parameters on boiling point of expressed oil.

\begin{tabular}{|c|c|c|c|c|c|c|}
\hline Source of Variation & SS & df & MS & F & P-value & F crit \\
\hline Pressure & 92.26889 & 2 & 46.13444 & 754.9273 & $6.98 \mathrm{E}-06$ & 6.944272 \\
\hline Temperature & 2.828889 & 2 & 1.414444 & 23.14545 & 0.006326 & 6.944272 \\
\hline Total & 95.34222 & 8 & & & \\
\hline
\end{tabular}

\section{Conclusion}

This study reveals the effect of heating temperature and applied pressure on the viscosity, specific gravity, refractive index and boiling point of oil mechanically expressed from watermelon seeds under uniaxial compression. This study reveals that while viscosity of the expressed oil consistently decreased with increase in heating temperature for all the pressure regimes under study and increased with increasing applied pressure for all temperature regimes under study, same process conditions did not affect the specific gravity of the expressed oil in a particular pattern.

The study further revealed that an increase in heating temperature and applied pressure during mechanical expression of oil from watermelon seeds results in a corresponding significant increase in the refractive index of the expressed oil. The study also shows that while increasing temperature reduces boiling point, increasing pressure increases the boiling point of oil mechanically expressed from watermelon seed. It is thus concluded that for optimal physical properties of oil expressed from watermelon seeds, temperature and pressure must be regulated.

\section{References}

1. Idouraine A, Kohlhepp EA, C W Weber (1996) Nutrient Constituents from Eight Lines of Naked Seed Squash (CucubitaPepo L) Journal of Agricultural Food Chemistry 44: 721-724.

2. Adejumo BA, Olorunsogo S T, Njoku CB (2015) Qualities of Watermelon Seed Oil Extracted at Different Moisture Content. International Journal of Advanced Engineering Research and Technology 3(3): 2348-8190.

3. Seyed MAR, M Elnaz (2006) Some Physical Properties of Watermelon Seeds. African Journal of Agricultural Research 1(3): 65-69.

4. Tarek A, Khaled MT (2001) Characteristics and Composition of Watermelon, Pumpkin, and Paprika Seed Oils and Flours. Journal of Agricultural Food Chemistry 49(3): 1253-1259.

5. NIFOR (2005) Training Manual for Small Scale Oil Palm fruits Processing Equipment Fabricators and Machine Operators. Published by Nigerian Institute for Oil Palm Research (NIFOR), Benin City.

6. AOAC (1991) Official Methods of Analysis. Association of Official AnalyticalChemists, Washington DC, USA.

7. Ozumba IC, Oje K, Ajiboye AT (2009) Development of a laboratory 
model mechanical palm kernel oil expeller Journal of agricultural engineering and technology (JAET) 17(1).

8. Ozumba IC and Oje K (2011) Some Physco-chemical characteristics of palm kernel oil mechanically expressed at different temperatures under uniaxial loading. Journal of agricultural engineering and technology (JAET) 19(2): 89-99.

9. Diemeleou CA, Zoue LT, Niamke SL (2014) Physicochemical and Nutritive Characterization of High Value Nonconventional Oil from Seeds of Amaranthus Hybridus Linn. European Scientific Journal 10(24): 100-115.

10. Codex Stan (1999) Standard for Named Vegetable Oils. Codex Alimenterus International Food Standards, 210: 10-11.
11. Aworanti OA, Agarry SE, Ajani AO (2012) A Laboratory Study of the Effect of Temperature on Densities and Viscosities of Binary and Ternary Blends of Soybean Oil, Soy Biodiesel and Petroleum Diesel Oil. Advances in Chemical Engineering and Science 2: 444-452.

12. Olaniyan AM (2006) Development of Dry Extraction Process for Recovering Shea Butter from Shea Kernel. Unpublished PhD thesis, Department of Agricultural Engineering, University of Ilorin, Nigeria.

13. Ajibola OO, Bakare FA, Adeeko KA, Fashina OO (1990) Effects of some Processing Factors on Yield of Oil Expressed from Rubber Seeds. Ife Journal of Technology 2(2): 1-7.

14. Fashina 00, Ajibola 00 (1989) Mechanical Expression of Oil from Canophor Nut (tetra-carpidiumconophorum). Journal of Agricultural Engineering Research 44: 275-287.

\section{Your next submission with Juniper Publishers will reach you the below assets}

- Quality Editorial service

- Swift Peer Review

- Reprints availability

- E-prints Service

- Manuscript Podcast for convenient understanding

- Global attainment for your research

- Manuscript accessibility in different formats

( Pdf, E-pub, Full Text, Audio)

- Unceasing customer service

Track the below URL for one-step submission https://juniperpublishers.com/online-submission.php 